\title{
Evaluation of the Biochemical Responses of Catfish (Clarias gariepinus Burchell, 1822) after Replacing Fish Oil with Plant-based Oils in their Diets
}

\author{
${ }^{* 1}$ EFFIONG, MMANDU U; AKPAN, ANTHONY W \\ ${ }^{1}$ Department of Zoology, University of Uyo, P.M.B. 1017, Uyo, Akwa Ibom State, Nigeria \\ *Correspondence Mobile: +234(0)803-625-5488; E-mail:sharonfisheries@yahoo.com
}

\begin{abstract}
This study evaluated biochemical responses of Clarias gariepinus after replacing fish oil with plantbased oils in their diets. The sources of oils were coconut, olive, crude palm, sunflower and sesame seed. These oils were incorporated at $7 \%$ level to produce five isonitrogenous $(41.03 \%$ protein) diets. The sixth diet contained fish oil and served as control experiment. Feeding trial was conducted in floating hapa $\left(1 \mathrm{~m}^{3}\right)$ system for 12 weeks. At harvest, blood samples were taken and examined for serum protein, albumin, globulin, electrolytes and tissue lipid peroxidation. Results showed that kidney function parameters (protein, albumin and globulin) increased significantly $(p<0.05)$ in palm oil treated group while the highest $(\mathrm{p}<0.05)$ serum ions were observed in olive oil treated fish. The amount of malondialdehyde (MDA) formed in fish tissues also increased $(\mathrm{p}<0.05)$ in palm oil group by $41 \%, 14 \%, 39 \%$ and $14 \%$ in the liver, kidney, gill and heart respectively. However, no significant difference $(\mathrm{p}>0.05)$ was observed in MDA formation in fish fed olive oil and control diets. Inferences from this study conclusively support the direct use of palm and olive oils as total replacement for fish oil in diets of Clarias gariepinus. CJASEM
\end{abstract}

\section{http://dx.doi.org/10.4314/jasem.v20i4.20}

Key Words: Clarias gariepinus, fish oil, plant oils, substitution, fish health, fish diet.

Aquaculture feed accounts for more than $50 \%$ cost in intensive aquaculture operations (NRC, 1993). The major concern in the industry is the fact that major ingredients (fish meal and fish oil) are scarce and expensive. The issues around the use of fish meal and fish oil in compound aquaculture diets are wideranging and complex (FIN, 2006). One of the main areas of contention is the presumption that although aquaculture production is expected to continue its rapid rise in the foreseeable future, catches from small pelagic fisheries, which are the sources of fish meal and oil are expected to remain static, or even decrease due to major drop in supply during the El Niño events of 1998 - 2004 (FAO, 2013). Fears have been raised that this trend may have disastrous consequences for the ecosystem, fuelling concerns that aquaculture may not be a net contributor to world fish supplies, but instead, adding more pressure on wild fisheries (Allan, 2004). In view of this, acceptable and economic alternative ingredients for aquaculture feed production must be found, or the further expansion of intensive aquaculture production would be constrained. There have been considerable research efforts to find suitable, cost-effective, nonconventional and terrestrial alternative ingredients which can totally or partially replace fish meal in aqua-feeds production (Ufodike et al., 2012). Presently, the most urgent problem to be solved in the industry relates to fish oil replacement.

The African catfish, Clarias gariepinus comprises the most commonly cultured fish in Nigeria (Adewumi and Olaleye, 2011). The health of this fish had been reported in terms of growth performances (Sotolu, 2010), length-weight relationships (Keke and Anene, 2011) and reproductive biology (Effiong et al., 2014).
However, the influences of these oils on catfish serum biochemistry and lipid peroxidation are very scanty. This study was conducted to assess the effects of replacing fish oil with plant-based oils on some biochemical components of Clarias gariepinus.

\section{MATERIALS AND METHODS}

Experimental design: The experimental setup composed of an outdoor concrete tank (8m x $5 \mathrm{~m} \times$ $1.65 \mathrm{~m}$ ) situated at the Vika Farms Limited, Mbak Etoi, Uyo, Akwa Ibom State. The farm is located at geographical coordinates of Latitude: $5^{\circ} 3^{\prime} 0^{\prime \prime}$ North and Longitude: $7^{\circ} 560^{\prime \prime}$ East. This tank was equipped with both inlet and outlet facilities and a 5,000 lit capacity overhead tank served as water reservoir. The experimental design was made up of a module consisting of $8.5 \mathrm{~m} \times 6.5 \mathrm{~m}$ bamboo raft with sixteen $1.5 \mathrm{~m} \times 1.5 \mathrm{~m}$ apartments fittable with sixteen $1 \mathrm{~m} \times$ $1 \mathrm{~m} \times 1 \mathrm{~m}$ hapas constructed and placed to fit on the concrete tank as described by Otubusin (2000).

Experimental diets preparation: Six isonitrogenous diets $(41.03 \%$ protein) were prepared using fishmeal, soybean meal, groundnut cake and corn flour as main ingredients (Table 1). In diet 1 (control), fish oil served as the lipid source. In diets 2 to 6 , coconut, olive, crude palm, sunflower and sesame seed oils were used as total replacement for fish oil respectively. The various oils were incorporated at $7 \%$ of the diet. All ingredients were procured at the same time to avoid variations associated with batch differences. They were carefully weighed out, mixed, made into pellets using $2 \mathrm{~mm}$ meat mincer, air-dried and labeled separately according to diets. 
Table 1: Ingredients ( $\mathrm{g} / \mathrm{kg}$ ) and proximate composition (\% dry weight) of experimental diets

\begin{tabular}{lcccccc}
\hline & Control & CCO & OLO & PMO & SFO & SSO \\
\hline Fishmeal & 186.0 & 186.0 & 186.0 & 186.0 & 186.0 & 186.0 \\
Soymeal & 186.0 & 186.0 & 186.0 & 186.0 & 186.0 & 186.0 \\
Groundnut cake & 375.0 & 375.0 & 375.0 & 375.0 & 375.0 & 375.0 \\
Corn flour & 182.0 & 182.0 & 182.0 & 182.0 & 182.0 & 182.0 \\
Lysine & 0.30 & 0.30 & 0.30 & 0.30 & 0.30 & 0.30 \\
Methionine & 0.30 & 0.30 & 0.30 & 0.30 & 0.30 & 0.30 \\
Fish premix* & 0.50 & 0.50 & 0.50 & 0.50 & 0.50 & 0.50 \\
Fish oil & 7.00 & - & - & - & - & - \\
Coconut oil & - & 7.00 & - & - & - & - \\
Olive oil & & & 7.00 & - & - & - \\
Crude palm oil & - & - & - & 7.00 & - & - \\
Sunflower oil & - & - & - & - & 7.00 & - \\
Sesame oil & - & - & - & - & - & 7.00 \\
Analyzed protein & 41.85 & 41.02 & 41.45 & 41.80 & 41.50 & 41.20 \\
Analyzed lipid & 18.57 & 15.92 & 17.03 & 17.82 & 17.47 & 17.40 \\
Gross energy (kJ/g) & 19.63 & 18.60 & 19.09 & 19.26 & 19.25 & 18.99 \\
\hline
\end{tabular}

Diets abbreviations: CCO: coconut oil; OLO: olive oil; PMO: crude palm oil; SFO: sunflower oil; SSO: sesame seed oil *Pfizer livestock product; $1 \mathrm{~kg}$ fish premix contains: Vitamin A=10,000,000I.U.D;D3=2,000,000I.U.D; $\mathrm{E}=23,000 \mathrm{mg} ; \mathrm{K} 3=2,000 \mathrm{mg} ; \mathrm{B} 1=3000 \mathrm{mg} ; \mathrm{B} 2=6,000 \mathrm{mg} ;$ niacin $=50,000 \mathrm{mg} ;$ calciumpathonate $=10,000 \mathrm{mg} ; \mathrm{B} 6=5000$ $\mathrm{mg} ; \mathrm{B} 12=25.0 \mathrm{mg}$; folicacid=1,000mg; biotin $=50.0 \mathrm{mg}$; cholinechloride $=400,000 \mathrm{mg} ;$ manganese $=120,000 \mathrm{mg} ;$ iron $=$ $100,000 \mathrm{mg} ;$ copper=8,500mg;iodine $=1,500 \mathrm{mg} ;$ cobalt=300mg;selenium=120mg;antioxidant $=120,000 \mathrm{mg}$.

Fingerling rearing: Each floating hapa was randomly stocked with Clarias gariepinus $(4.5 \pm 0.10 \mathrm{~g})$ at 20 fish per rearing system. Experimental diets were fed to triplicate groups of fish at $5 \%$ of their body weight. This amount was divided into three equal portions and fed at 08:00, 13:00 and 18:00hrs respectively over a period of twelve weeks.

Sample collection: At the end of the feeding trial, 5 $\mathrm{ml}$ blood per fish was collected from vertebral blood vessel using $2 \mathrm{ml}$ disposable syringes and needle and transferred to plain sample bottles. The separation of serum from whole blood was performed by centrifugation using a bench top centrifuge at 3,000 rpm for 15 minutes at $25^{\circ} \mathrm{C}$. The serum (supernatant) was transferred into well-labelled sample bottles using a Pasteur pipette and stored in a refrigerator at a temperature of $4^{0} \mathrm{C}$ for biochemical analyses.

Biochemical measurements: The concentration of total protein level in serum was determined by biuret method (Henry et al., 1974) using standard Fortress diagnostic kit. Serum ions: bicarbonate $\left(\mathrm{HCO}_{3}{ }^{+}\right)$, sodium $\left(\mathrm{Na}^{+}\right)$, chloride $\left(\mathrm{Cl}^{-}\right)$and potassium $\left(\mathrm{K}^{+}\right)$were analyzed colorimetrically (Henry et al., 1974) using standard Parksha Neochem analysis kit. Lipid peroxidation was determined by measuring malondialdehyde formation in fish tissues (liver, kidney, heart and gills) as described by Bull and Marnett (1985). All biochemical analyses were carried out at Biochemistry laboratory, University of Uyo.
Economic analysis: These were calculate thus:

Cost of feeding $=$ Price of feed $\mathrm{x}$ total feed intake

Profit index $=$ Value of fish $(\mathrm{N}) / \operatorname{cost}$ of feed $(\mathbb{N})$

Economic conversion ratio $=$ Cost of diet $\mathrm{x}$ food conversion ratio

Statistical analysis: Data analyses were carried out using Statistical Package for Social Sciences (SPSS 19.0, 2010 version) and level of significance was set at $\mathrm{p} \leq 0.05$.

\section{RESULTS AND DISCUSSION}

The results of biochemical parameters of catfish fed different oil diets (Table 2) showed that fish fed palm oil-based diet had the highest $(\mathrm{p}<0.05)$ total protein $(5.42 \mathrm{mmol} / \mathrm{l})$, albumin $(2.98 \mathrm{mmol} / \mathrm{l})$ and globulin $(2.06 \mathrm{mmol} / \mathrm{l})$ while those fed the control diet had the least $(\mathrm{p}<0.05)$ values of $2.97 \mathrm{mmol} / \mathrm{L}, 1.63 \mathrm{mmol} / \mathrm{L}$ and $1.13 \mathrm{mmol} / \mathrm{L}$ for total protein, albumin and globulin respectively. It might be mentioned here that immune bodies in fish are associated with the globulin concentration. Therefore, palm oil supported the immune function of this fish. No significant differences $(p>0.05)$ existed in albumin/globulin ratios in all the treatments. Serum ionic concentrations followed a different trend. Fish fed olive oil-based diets had the best $(\mathrm{p}<0.05)$ values of $\mathrm{Na}^{+}(134.44 \mathrm{mg} / 1000 \mathrm{~g}), \mathrm{K}^{+}(4.54 \mathrm{mg} / 1000 \mathrm{~g}), \mathrm{Cl}^{-}$ $(176.58 \mathrm{mg} / 1000 \mathrm{~g})$ and $\mathrm{HCO}_{3}{ }^{+}(27.67 \mathrm{mg} / 1000 \mathrm{~g})$ while the least $(\mathrm{p}<0.05)$ values were recorded in fish fed sesame seed oil diets. 
Table 2: Serum biochemical parameters of Clarias gariepinus fingerlings fed diets in which different plant-based oils replaced fish oil shown alongside initial levels.

\begin{tabular}{lcccccc}
\hline & Control & CCO & OLO & PMO & SFO & SSO \\
\hline $\mathrm{TP}^{1}$ & $2.97 \pm 0.03^{\mathrm{a}}$ & $3.85 \pm 0.44^{\mathrm{c}}$ & $3.56 \pm 0.38^{\mathrm{bc}}$ & $5.42 \pm 0.32^{\mathrm{d}}$ & $3.02 \pm 0.29^{\mathrm{b}}$ & $3.23 \pm 0.22^{\mathrm{b}}$ \\
$\mathrm{A}^{2}$ & $1.63 \pm 0.01^{\mathrm{a}}$ & $2.11 \pm 0.24^{\mathrm{c}}$ & $1.96 \pm 0.21^{\mathrm{bc}}$ & $2.98 \pm 0.18^{\mathrm{d}}$ & $1.66 \pm 0.16^{\mathrm{b}}$ & $1.78 \pm 0.1^{\mathrm{b}}$ \\
$\mathrm{G}^{3}$ & $1.13 \pm 0.01^{\mathrm{a}}$ & $1.46 \pm 0.17^{\mathrm{c}}$ & $1.35 \pm 0.14^{\mathrm{bc}}$ & $2.06 \pm 0.12^{\mathrm{d}}$ & $1.15 \pm 0.11^{\mathrm{b}}$ & $1.23 \mathrm{v} 0.09^{\mathrm{b}}$ \\
$\mathrm{A} / \mathrm{G}$ ratio & $1.44 \pm 0.25$ & $1.44 \pm 0.52$ & $1.45 \pm 0.19$ & $1.44 \pm 0.66$ & $1.44 \pm 0.35$ & $1.44 \pm 0.72$ \\
$\mathrm{Na}^{+4}$ & $127.81 \pm 0.7^{\mathrm{c}}$ & $130.61 \pm 0.4^{\mathrm{d}}$ & $134.44 \pm 0.2^{\mathrm{f}}$ & $132.91 \pm 0.1^{\mathrm{e}}$ & $125.26 \pm 0.8^{\mathrm{b}}$ & $120.15 \pm 0.7^{\mathrm{a}}$ \\
$\mathrm{K}^{+5}$ & $2.91 \pm 0.02^{\mathrm{b}}$ & $4.08 \pm 0.04^{\mathrm{d}}$ & $4.54 \pm 0.05^{\mathrm{e}}$ & $4.33 \pm 0.04^{\mathrm{d}}$ & $3.03 \pm 0.01^{\mathrm{c}}$ & $2.75 \pm 0.04^{\mathrm{a}}$ \\
$\mathrm{Cl}^{-6}$ & $113.52 \pm 3.1^{\mathrm{b}}$ & $153.15 \pm 4.7^{\mathrm{d}}$ & $176.58 \pm 2.6^{\mathrm{e}}$ & $151.35 \pm 9.3^{\mathrm{d}}$ & $126.12 \pm 7.8^{\mathrm{c}}$ & $102.7 \pm 6.2^{\mathrm{a}}$ \\
$\mathrm{HCO}_{3}{ }^{+7}$ & $19.67 \pm 0.33^{\mathrm{b}}$ & $22.33 \pm 1.33^{\mathrm{c}}$ & $27.67 \pm 0.33^{\mathrm{f}}$ & $27.0 \pm 0.57^{\mathrm{e}}$ & $25.0 \pm 0.57^{\mathrm{d}}$ & $18.67 \pm 0.33^{\mathrm{a}}$ \\
\hline
\end{tabular}

Data are means \pm standard error. *Means in the same row with the same superscripts were not significantly different $(\mathrm{p}>0.05)$. Where: ${ }^{1}$ total protein $(\mathrm{mmol} / \mathrm{l}) ;{ }^{2}$ albumin $(\mathrm{mmol} / \mathrm{l}) ;{ }^{3}$ globulin (mmol/l); ${ }^{4}$ sodium (mg/1000g); ${ }^{5}$ potassium $(\mathrm{mg} / 1000 \mathrm{~g}) ;{ }^{6}$ chloride $(\mathrm{mg} / 1000 \mathrm{~g}) ;{ }^{7}$ bicarbonate $(\mathrm{mg} / 1000 \mathrm{~g})$.

A significant increase $(\mathrm{p}<0.05)$ in lipid peroxidation (as malondialdehyde formation) was observed in fish tissues (liver, kidney, gills and heart) following exposure to different oil-based diets (Table 3). Fish fed palm oil diet, exhibited the highest percent MDA formation of $41 \%, 14 \%, 39 \%$ and $14 \%$ compared to the initial levels in the liver, kidneys, gills and heart respectively. These results indicated that reactive oxygen species may be associated with the metabolism of crude palm oil leading to peroxidation of membrane lipids of the respective organs. However, no significant difference $(p>0.05)$ was observed in MDA formation in fish groups fed olive, sunflower, sesame and the control diets.

Table 3: The formation of MDA (nmol/mg net tissue) in the liver, kidneys, gills and heart of Clarias gariepinus fed different oil diets.

\begin{tabular}{|c|c|c|c|c|c|c|c|}
\hline $\begin{array}{l}\text { Source of } \\
\text { Tissue }\end{array}$ & Initial & Control & $\mathrm{CCO}$ & OLO & PMO & SFO & SSO \\
\hline Liver & $1.84 \pm 0.07^{\mathrm{a}}$ & $2.12 \pm 0.19^{\mathrm{ab}}$ & $2.23 \pm 0.11^{\mathrm{b}}$ & $2.03 \pm 0.04^{\mathrm{ab}}$ & $2.59 \pm 0.07^{\mathrm{c}}$ & $1.97 \pm 0.01^{\mathrm{ab}}$ & $2.01 \pm 0.02^{\mathrm{ab}}$ \\
\hline Kidneys & $1.75 \pm 0.03^{\mathrm{a}}$ & $1.78 \pm 0.06^{\mathrm{a}}$ & $1.96 \pm 0.06^{\mathrm{bc}}$ & $1.84 \pm 0.03^{\mathrm{ab}}$ & $2.00 \pm 0.03^{c}$ & $1.75 \pm 0.04^{\mathrm{a}}$ & $1.86 \pm 0.03^{\mathrm{ab}}$ \\
\hline Gills & $1.17 \pm 0.09^{\mathrm{a}}$ & $1.37 \pm 0.04^{\mathrm{bc}}$ & $1.44 \pm 0.05^{\mathrm{bc}}$ & $1.40 \pm 0.03^{\mathrm{bc}}$ & $1.62 \pm 0.05^{\mathrm{d}}$ & $1.30 \pm 0.01^{\mathrm{ab}}$ & $1.51 \pm 0.05^{\mathrm{cd}}$ \\
\hline Heart & $1.55 \pm 0.06^{\mathrm{a}}$ & $1.64 \pm 0.05^{\mathrm{abc}}$ & $1.61 \pm 0.03^{\mathrm{abc}}$ & $1.70 \pm 0.07^{\mathrm{bc}}$ & $1.77 \pm 0.04^{\mathrm{c}}$ & $1.53 \pm 0.04^{\mathrm{a}}$ & $1.72 \pm 0.04^{\mathrm{c}}$ \\
\hline
\end{tabular}

Data are means \pm standard error. *Means in the same row with the same superscript were not significantly different $(\mathrm{p}>0.05)$.

The economic evaluation of experimental diets showed that palm oil diet gave the best profit index (27.97) and economic conversion ratio (6.04) while the control diet had the poorest of these variables (Table 4).

Table 4: Economic evaluation of experimental diets

\begin{tabular}{lllllll}
\hline Indices & Control & CCO & OLO & PMO & SFO & SSO \\
\hline $\mathrm{FFW}^{1}$ & $213.2 \pm 1.14^{\mathrm{b}}$ & $188 \pm 1.37^{\mathrm{a}}$ & $209.2 \pm 1.85^{\mathrm{b}}$ & $236.6 \pm 3.7^{\mathrm{c}}$ & $203 \pm 2.9^{\mathrm{b}}$ & $171.7 \pm 1.3^{\mathrm{a}}$ \\
$\mathrm{QFP}^{2}$ & $4194.4 \pm 93^{\mathrm{c}}$ & $3697.5 \pm 72^{\mathrm{b}}$ & $4115.9 \pm 104^{\mathrm{c}}$ & $4672.8 \pm 25^{\mathrm{d}}$ & $3998.7 \pm 113^{\mathrm{c}}$ & $3434.7 \pm 25^{\mathrm{a}}$ \\
$\mathrm{PI}^{3}$ & $15.16 \pm 0.1^{\mathrm{a}}$ & $27.42 \pm 0.1^{\mathrm{de}}$ & $23.33 \pm 0.2^{\mathrm{b}}$ & $27.97 \pm 0.5^{\mathrm{e}}$ & $25.32 \pm 0.5^{\mathrm{c}}$ & $26.71 \pm 0.1^{\mathrm{a}}$ \\
$\mathrm{VOF}^{4}$ & $2,097.18 \pm 5^{\mathrm{c}}$ & $1,848.77 \pm 36^{\mathrm{b}}$ & $2,057.95 \pm 52^{\mathrm{c}}$ & $2,336.4 \pm 12^{\mathrm{d}}$ & $1,999.34 \pm 56^{\mathrm{c}}$ & $1717.33 \pm 12^{\mathrm{a}}$ \\
$\mathrm{ECR}^{5}$ & $11.02 \pm 0.14^{\mathrm{d}}$ & $6.11 \pm 0.28^{\mathrm{a}}$ & $7.18 \pm 0.09^{\mathrm{c}}$ & $6.04 \pm 0.00^{\mathrm{a}}$ & $6.57 \pm 0.1^{\mathrm{b}}$ & $6.49 \pm 0.00^{\mathrm{b}}$ \\
\hline
\end{tabular}

*Means in the same row with the same superscript were not significantly different $(\mathrm{p}>0.05)$.

Where: ${ }^{1}$ Fish final weight $(\mathrm{g}) ;{ }^{2}$ quantity of fish produced $(\mathrm{g}) ;{ }^{3}$ profit index; ${ }^{4}$ value of fish $(\mathrm{N}) ;{ }^{5}$ economic conversion ratio.

Studies have revealed that substantial use of vegetable oils as energy sources in fish diets yielded positive growth responses in fish (Babalola and Adebayo, 2007). The results obtained in this study have shown that plant-based oil sources could be used as excellent nutrient base in catfish feed manufacture. All the experimental diets were adequately consumed by fish and fish showed no sign of stress. This may imply that there was no palatability problem and feed were adequately utilized. This report is similar to the observation of Aderolu and Akinyemi (2009) in the utilization of coconut and peanut oil diets and Sotolu (2010) in the utilization of sesame seed and palm oil diets by Clarias gariepinus. Ochang et al. (2007) earlier showed that vegetable oils can replace fish oil up to $12.5 \%$ inclusion level in catfish diets without feed intake associated problems. The $7 \%$ inclusion levels of the various oils used in the present study appeared to be within acceptable limits that ensured balances in lipid components for normal catfish growth (NRC, 1993).

Serum proteins play a key role in maintaining osmotic pressure and viscosity of fish blood. Of particular interest is the correlation of the albuminglobulin ratio which low levels have been linked to nephrosis in fishes (Sandnes et al., 1988). Moreover, it has been established that serum albumin plays the predominating role in exerting osmotic pressure of 
the proteins. Different kinds of fish vary sharply in the total serum proteins and in the distribution of the various fractions. The Elasmobranchii, for instance, are known to use urea which is present in their blood in very large amounts to maintain the osmotic pressure of their blood approximately equal to that of their environment. In teleosts (such as catfish), it has become a matter of interest to determine whether lipid type has any influence upon the concentration and distribution of their serum proteins. The data presented in this study revealed that the concentrations of serum proteins were in normal range which, indicated that the animals were apparently healthy throughout the experimental period (Sandnes et al., 1988).

Clinical diagnosis of disease and damage to the structural integrity of fish is commonly assessed by monitoring the level of malondialdehyde (MDA) formation in fish tissues such as liver, kidney, gills and heart. High levels of MDA in animal tissues have been found in response to oxidative stress induced by hyperthyroidism (Subudhi et al., 2008). In this study these parameters were insignificantly $(p>0.05)$ altered by the experimental diets, suggesting that no critical injury was caused by fish oil substitution with vegetable oils and vegetable oils did not exert any deleterious effects on the liver, kidney, gills and heart of catfish.

Economic evaluation of diets showed that cost of feed was minimized by replacing fish oil with coconut, olive, crude palm sunflower and sesame seed oils in catfish diets. This assertion is buttressed by the relative similar profit index obtained from using the various plant oil diets. The trend of the results indicated that though any of the five plantbased oils could be used in the production of catfish feed production; crude palm oil was the healthiest oil and is hereby recommended for use in aqua-feed industry.

Conclusion: High serum levels of total protein, albumin and globulin were recorded in fish fed palm oil-based diet while the best serum ions were observed in group treated with olive oil-based diet. The elevated levels of malondialdehyde recorded in fish fed palm oil diet had not been linked to any negative health effect in fish. The authors hereby recommend palm oil as total replacement for fish oil in catfish feed production.

\section{REFERENCES}

Aderolu, ZA; Akinremi, OA (2009). Dietary Effects of Coconut Oil and Peanut Oil in Improving Biochemical Characteristics of Clarias gariepinus Juvenile. Turkish Journal of Fish and Aquatic Sciences 9: 105-110.
Adewumi, AA; Olaleye, VF (2011). Catfish Culture in Nigeria: Progress, Prospects and Problems. African Journal of Agricultural Research 6 (6): 1281-1285

Allan, G (2004). Fish for Feed vs. Fish for Food. In: Brown AG (ed), Fish, Aquaculture and Food Security: Sustaining Fish as a Food Supply, Canberra: Parliament House, pp. 20-26.

Babalola, TO; Adebayo, MA (2007). Effects of Dietary Lipid on Levels of Growth Performance and Feed Utilization by Heterobranchus longifilis Fingerlings. Journal of Fisheries International 2 (1): 60-64.

Bull, AW; Marnett, LJ (1985). Lipid Peroxidation Assay. Anal. Biochem. 1: 149- 284.

Effiong, MU; Akpan, AW; Ayotunde, EO (2014). Effect of Feeding Different Dietary Protein Levels on Reproductive Biology of African Mud Catfish (Clarias gariepinus). Journal of Aquatic Sciences 29 (1B): 113-124.

FAO (2013). Global Aquaculture Production Statistics for the Year 2011. Retrieved from: (http://www.fao.org/fishery/topic/16140/en

FIN (Fishmeal Information Network) (2006). Annual Review of the Feed Grade Fish stocks used to produce fishmeal and fish oil for the UK market. FIN Dossier, p54.

Henry, R; Canon, DC; Winkelman, JW (1974). The Colorimetric Determination of Serum Triglycerides, Clinical Chemistry 29; 538-542.

Keke, IR; Anene, A (2011). Length-Weight Relationship and Fecundity of Clarias gariepinus from River Niger. Journal of Aquatic Sciences 26 (1): 1-7.

NRC (National Research Council) (1993). Nutrient Requirements of Fish. Washington, D.C: National Academy Press, p 114.

Ochang, SN; Fagbenro, OA; Adebayo, OT (2007). Growth Performance, Body Composition, Haematology and Product Quality of the African Catfish (Clarias gariepinus) fed Diets with Palm Oil. Pakistan Journal of Nutrition 6 (5): 452459.

Otubusin, SO (2000). The Effect of Feedstuffs on Tilapia, Oreochromis niloticus fry in Floating Net-Hapas. Nig. J. of Science 34 (4): 377-379.

Sandnes, K; Lie, O; Waagbo, R (1988). Normal Ranges of some Blood Chemistry Parameters in 
Adult Farmed Atlantic Salmon, Salmo salar. J. Fish Biology 32: 129 - 136.

Sotolu, OA (2010). Feed Utilization and Biochemical Characteristics of Clarias gariepinus (Burchell, 1822) Fingerlings fed Diets Containing Fish oil and Vegetable Oils as Total Replacements. World J. Fish Marine Sciences 2 (2): 93-98.
Stress and Oxygen Consumption of L-thyroxine Induced Hyperthyroid Rat Liver Mitochondria by Vitamin E and Curcumin. Chem. Biol. Interact. 173: 05 - 114.

Ufodike, EBC; Usman, M; Effiong, MU (2012). Substitution of Earthworm Meal with a Portion of Fishmeal in Diets of Nile tilapia (Oreochromis niloticus). Journal of Aquatic Sciences 12 (1): 29-33.

Subudhi, U; Dasa, K; Paital, B; Bhanja, S; Chainy, GBN (2008). Alleviation of Enhanced Oxidative 